
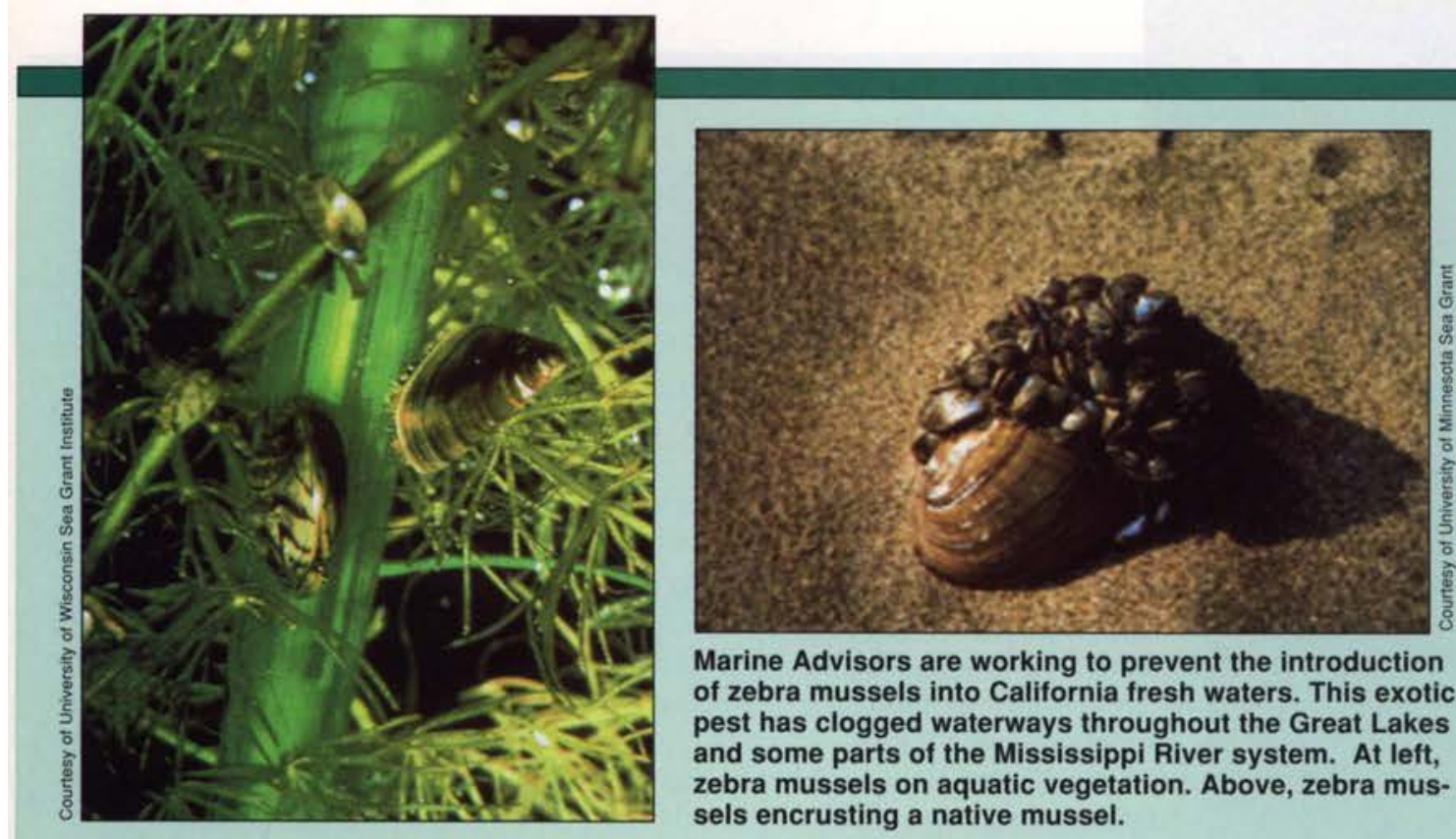

Marine Advisors are working to prevent the introduction of zebra mussels into California fresh waters. This exotic pest has clogged waterways throughout the Great Lakes and some parts of the Mississippi River system. At left, zebra mussels on aquatic vegetation. Above, zebra mussels encrusting a native mussel.

\title{
Public education to thwart aquatic nuisances
}

\author{
Jodi L. Cassell
}

California's roughly 1,600 miles of aqueducts and pipelines are a lifeline to its cities and agricultural regions. Imagine the potential threat presented by an alien invader so prolific that it could clog these water systems - an invader so voracious that it could alter the ecology of the state's freshwater ecosystems. This scenario is not some fantastic invention of the "X-Files", but rather a probable depiction of what will happen if a small freshwater mussel makes its way to California and the other western states.

The organism is the European zebra mussel (Dreissena polymorpha). Originally a native of western Russia, it was introduced to Europe in the 18th and 19th centuries. In 1988 this nonindigenous (or "exotic") species was discovered in the Great Lakes (Lake St. Clair), most likely introduced in ship ballast water (Snyder et al. 1994).

The zebra mussel is highly prolific, readily attaches to objects such as boats and plants and has a prolonged free-swimming larval stage. All of these factors, and a lack of natural predators, have facilitated its spread to 19 U.S. states and 2 Canadian provinces in the years since its discovery (U.S. Army Corps of Engineers 1994).

The zebra mussel has had dramatic ecological and economic impacts in the Great Lakes, and Sea Grant programs in this region have engaged in extensive research and public education efforts to contain the species. Most of the economic effects have resulted from the mussel's ability to colonize the surfaces of structures like water-intake pipes at power and water treatment plants; they can completely clog intake pipes up to 24 inches diameter. Costs from plant shutdowns and from mussel removal efforts have been very high - control costs in the Great Lakes region totaled approximately \$120.4 million over the 5-year period 1989 to 1994 (Great Lakes Panel on Aquatic Nuisance Species 1996).

Luckily, zebra mussel populations have not yet been found west of the Rocky Mountains. If introduced, however, it is believed that the species would spread quickly in the freshwater ecosystems and water-delivery systems and canals of the West. The entire length of the California aqueduct would provide ideal habitat because of its concrete substrate and because water flows are not fast enough to prevent attachment of the mussel (Janik 1996a). Not only would control costs be very high but municipal and agricultural water-delivery systems could be significantly affected.

We could also expect significant ecological impacts, as well as impacts to important fish populations. Zebra mussels are filter-feeders and are able to filter about 1 liter of water per day, which may affect the amount of food available for other animals in the ecosystem. Salmon species would also be affected if zebra mussels 


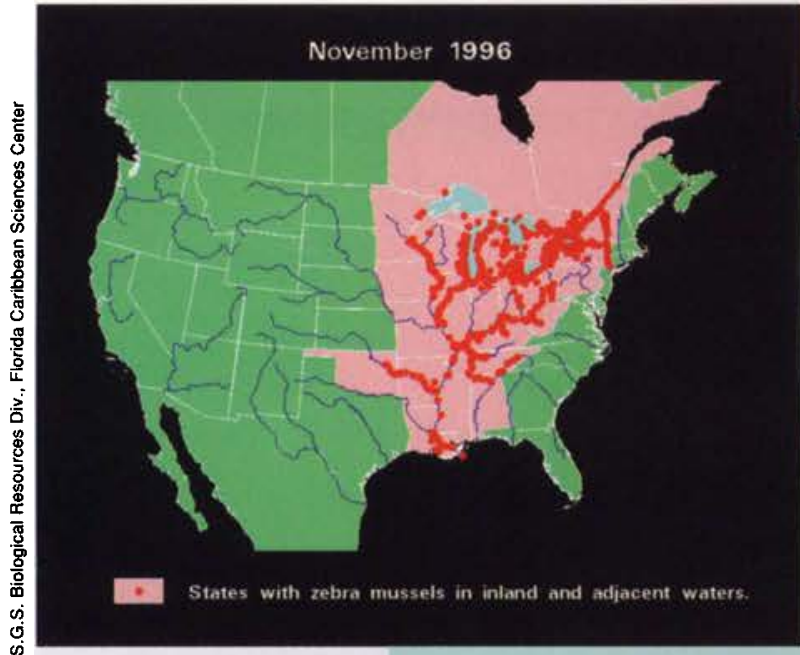

Fig. 1. Zebra mussel distribution in the United States.

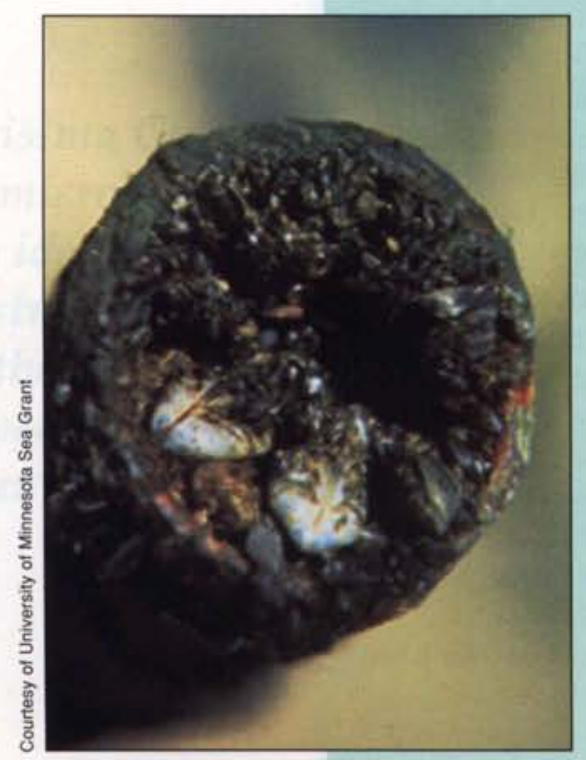

The zebra mussel can completely clog intake pipes up to 24 inches diameter. colonized fish screens and other structures used to prevent entrainment of juvenile fish (Zook 1995).

How might they get here? Probably by hitching a ride. Recreational boats being transported from one body of water to another are the most likely vector for zebra mussel introduction. Depending on environmental conditions, the animals can live for as long as 10 to 15 days out of water, and thus could survive a trip from the Midwest to California attached to boat hulls, motors or water intakes. Larval mussels could also be transported in the live wells, bilge and internal parts of motors and trailers of vessels (Zook 1995). Other potential pathways of zebra mussel introduction include ballast water from commercial shipping and shipments of aquatic plants and live baitfish (Janik 1996b).

Because of the threat posed by this species, the State of California passed a law in 1993 declaring zebra mussels an injurious species and initiated a program of inspecting boats entering the state at border Agricultural Inspection Stations. The effort is spearheaded by the Department of Water Resources, the Department of Food and Agriculture and the Department of Fish and Game.

Indeed, recent experience confirms the threat. Since October 1993, 11 boats entering California have been found to carry adult zebra mussels. On three occasions the transported mussels were alive at the time of inspection (Janik 1996b).

California's past experience with similar aquatic nuisances, such as the exotic weed hydrilla (Hydrilla verticillata), also points to the wisdom of such a proactive approach. Since hydrilla was introduced to California 20 years ago, it has been spread to drainages throughout the state by boaters and other transport mechanisms. State and federal agency cooperators have spent nearly $\$ 1$ million per year on programs to eradicate the weed from state waters (Anderson 1996).

Given the low level of public awareness of issues related to nonindigenous species, public education on nonindigenous species is one major objective of the Sea Grant program of the San Francisco Bay Area counties. In late 1996, the U.S. Fish and Wildlife Service provided funding for California Sea Grant Extension to augment existing state efforts with a pilot boater-education strategy for the 12-county San Francisco BayDelta region. The program will run through November 1997. Additional support for the project is being provided by West Marine, California Department of Boating and Waterways and California Sea Grant College System. Educational materials developed by Sea Grant Extension colleagues in Minnesota and other states are being adapted for use in the West. The project includes an evaluation of the current level of awareness among recreational boaters; distribution of educational materials including brochures and signage at marinas; and a series of workshops for individuals involved in boater education and boating facility management.

Longer term, we expect to extend this program to other regions of California and the West in cooperation with other Pacific Sea Grant programs and the Western Zebra Mussel Task Force, which is composed of state and federal agency personnel from western states and others interested in the issue. A second long-term goal is to develop a Pacific regional public outreach strategy, in partnership with Sea Grant's nationwide zebra mussel training initiative. This would include area workshops and multimedia programs for the general public and resource managers on zebra mussels and other nonindigenous species.

Of course, zebra mussels would be only the latest in a long stream of invaders of California's freshwater and marine ecosystems. The San Francisco Bay-Delta region, with more than 200 established nonindigenous species, has been described as "the most invaded aquatic ecosystem in North America" (Cohen and Carlton 1995). Introduced species range from the South American water hyacinth to the striped bass (now one of the most important game fish in the estuary). Recent arrivals include a number of species that have the potential to cause serious ecological and economic harm, such as the Asian clam, the Chinese mitten crab and Atlantic cordgrass.

Congress recently signaled its appreciation of the seriousness of the problem nationwide by 
passing H.R. 4283, the National Invasive Species Act, which seeks to prevent the introduction and spread of nonindigenous species by ballast water operations in U.S. waters.

But what, specifically, can be done to lessen the impact of these alien invaders? To address this question, we organized a California Sea Grant Program Development Workshop this past October, for scientists and government policy makers who are concerned about the problem. Our objective was to provide education about research efforts that are under way and to identify future research, management and education needs related to aquatic nuisance species. The results will be published by California Sea Grant later this year (California Sea Grant, in press).

By forming linkages between academic and agency scientists and managers, and by providing broad outreach activities aimed at educating the general public, California Sea Grant's extension advisors can make an important contribution to addressing this issue.

J.L. Cassell is UC Cooperative Extension Sea Grant Marine Advisor for the San Francisco Bay counties.

\section{References}

Anderson LWJ, 1996. Eradicating California's hydrilla Aquatic Nuisance Species Digest 1(3). Navarre (MN): Freshwater Foundation. p. 25-33.

California Sea Grant. Forthcoming. Proceedings from the October 1996 workshop on Nonindigenous Species: Current status and research needs. Millbrae, CA. 30 p.

Cohen AN, Carlton JT. 1995. Nonindigenous aquatic species in a United States estuary: A case study of the biological invasions of the San Francisco Bay and Delta. Biological study. Springfield (VA): U.S. Department of Commerce, NTIS. $285 p$

Great Lakes Panel on Aquatic Nuisance Species (Great Lakes Commission). 1996. ANS Update 2(1):5 Janik J. 1996a. Personal communication. State of California, Department of Water Resources, Sacramento, CA.

Janik J. 1996b. Presentation at the October 18-19, 1996, California Sea Grant Nonindigenous Species Workshop, Millbrae, CA.

Snyder FL et al. 1994. Zebra Mussels in North America: The Invasion and Its Implications. Columbus $(\mathrm{OH})$ : Ohio Sea Grant College Program. 4 p.

U.S. Army Corps of Engineers. 1994. Zebra musse research: Technical notes. Compiled by Zebra Mussel Research Program. Vicksburg (MI): Waterways Experiment Station. $98 \mathrm{p}$.

Zook WJ. 1995. An Assessment of the Potential for Introduction, Local Adaptation, and Environmental Impact of the Zebra Mussel in Washington State. State of Washington, Department of Fish and Wildlife, Olympia (WA). $18 \mathrm{p}$. continued from $p .18$

health aspects of fishing in the San Francisco Bay. Bay Area health officials are concerned that potentially dangerous levels of PCBs, mercury and other pollutants are making their way into the fish-heavy diets of recent Southeast Asian immigrants. In collaboration with Cooperative Extension nutritionists, Cassell is developing materials for the region's public health care professionals to educate this at-risk group. The plan is to educate them through cooking demonstrations

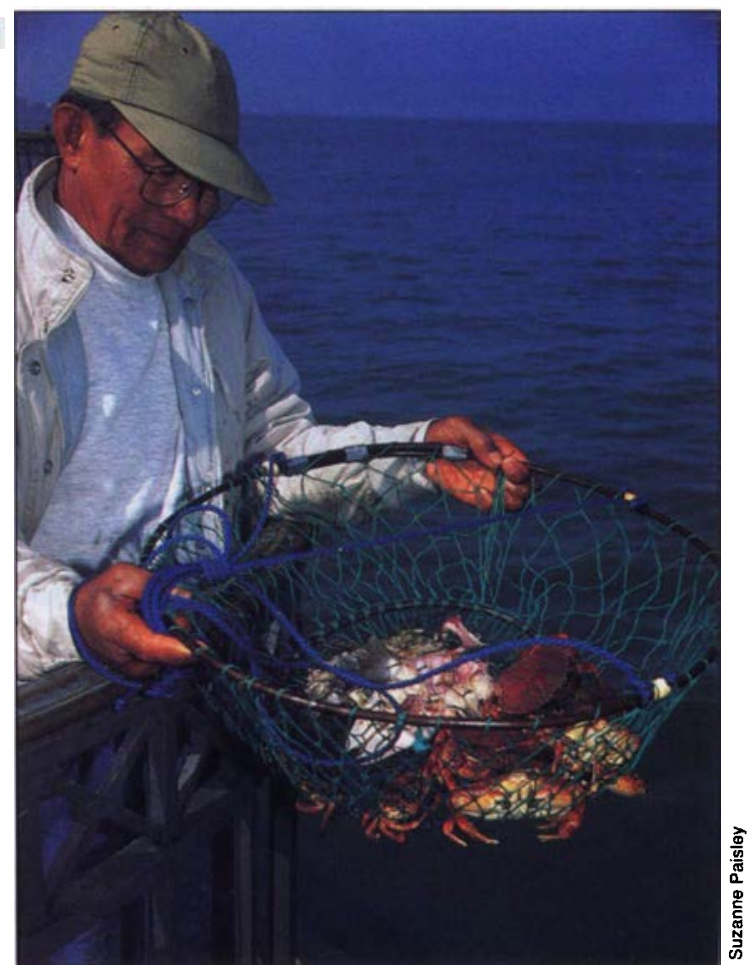

and other means about preparing fish safely and avoiding unsafe parts altogether.

Another facet of Cassell's work involves educating the shipping industry and the general public about the threats posed by exotic species, particularly fast-spreading zebra mussels, which not only threaten to displace native species but can clog public water systems (see page 19).

\section{Ensuring seafood safety}

One of the biggest challenges in the early days of the Sea Grant Extension Program was just getting noticed. "When we first started, Chris Dewees and I did a lot of consumer education - how to buy fish, what species were available - to get the Sea Grant name out there," said Bob Price, the extension specialist in seafood safety and technology.

Seafood processors were particularly skeptical. "They had no contact with extension, no clue what we were about," Price said. "I was even asked to leave a few places. I had to convince them that I wasn't there to steal trade secrets or to regulate them."

In the 25 years since, Price has developed a variety of projects helping seafood processors tap into new technologies; showing retailers how to tighten sanitation practices; and educating consumers in safety and quality (see page 50 ). His efforts have earned him a national reputation for seafood safety education and accolades from the Institute of Food Technologists and the California Fisheries and Seafood Institute.

Seafood consumption has grown dramatically in recent years, and with it a concern about the
The seafood-heavy diets of Southeast Asian immigrants make them particularly at risk for consuming potentially dangerous levels of PCBs, mercury and other pollutants. 